\title{
THE NEGATION JANGAN FROM A LEXICAL FUNCTIONAL PERSPECTIVE
}

\author{
Truly Almendo Pasaribu \\ Sanata Dharma University \\ tr.almendo@gmail.com
}

\begin{abstract}
This paper is an investigation into the properties of the negation jangan in the framework of Lexical-Functional Grammar. The analysis shows that the negation jangan can negate verbs functioning as predicate in a sentence. It follows both transitive and intransitive verbs. The constituent that fills the position in the subject is defined by the voice of the sentence. If it is in the active voice, the subject is the second person pronoun. On the other hand, if the word jangan negates passive voice, the subject is not restricted. It is possible in Indonesian sentence to have double negation because the negative adverb jangan can negate a negation tidak. It also follows adjectives, adverbs, nouns and clauses. The negation jangan also has a different grammatical construction when it precedes the preposition sampai. The subject following jangan sampai is not restricted as the subject following jangan sampai is in active voice. The word jangan can be fronted to modify the whole clause.
\end{abstract}

Keywords: negation, Lexical Functional Grammar, jangan

\section{Introduction}

Negation is an old topic in language starting from Aristotle who comes out with the idea about logic. He clearly attaches the greatest importance to this topic (Horn, 1978 in Sudaryono, 1993). Negation plays a very important function in a language. The importance of negation is assumed to be universal (Lehman, 1972). In a verbal communication, human uses negation as devices to deny something. Negation stated the opposite of the affirmative statement. Talmy (2001, p. 388) mentions that "negation is one of the most consistently grammaticalized modalities". Nonetheless, most languages show some diversity of negation markers, so that in some grammatical contexts - admittedly infrequent and highly marked — special negation markers may be used. In Indonesia negative constituents can be expressed in the form of bound morpheme, like $a-$, non-, tuna- and free morphemes, such as tidak, bukan, jangan. In this short paper, we will not discuss about all negations in Indonesia, but we will concentrate on the unique form of the word jangan.

The negative constituent jangan marks the negative form of imperatives. An imperative is used by the speaker to express requests, orders, and condition to the hearer. The second person subject is usually omitted (Finnegan, 1992). Imperative sentences are divided into affirmative imperatives and negative imperatives (Sudaryono, 1993:99). The word jangan semantically is used to indicate imperative and also negative sentence. The word has a unique behavior compared to other negative constituent such as bukan and tidak. Negative constituent jangan is used when we want to negate a positive imperative. For example:

1) Buka pintunya!

2) Tidak buka pintunya!*

3) Bukan buka pintunya!*

4) Jangan buka pintunya! 
We cannot use other negation for imperative sentences. However, we can paraphrase the word jangan with the word dilarang (Alwi, 1992:191), as shown in the example below:
5) Dilarang
buka pintu=nya!
Prohibit.pass open door the
It is prohibited to open the door.

The data found in the corpus show different grammatical patterns of sentences containing the word jangan. This paper is an investigation into the properties of the negative constituent jangan in the framework of Lexical-Functional Grammar. Lexical-Functional Grammar (LFG) Lexical Functional Grammar (LFG) is a nontransformational theory of linguistic structure which assumes that language is "best described and modeled by parallel structures representing different facets of linguistic organization and information, related to one another by means of functional constraints" (Dalrymple, 2001, p.1). The theory models language as a set of parallel representations, each of which has to satisfy the constraints appropriate to that type of representation, and which together have to satisfy constraints on the correspondence between types of representation. LFG is a lexicalist, declarative, constraint based theory of generative grammar. The theory has also proven useful for descriptive or documentary linguistics. "LFG posits two syntactic structures: constituent structure (cstructure) which is occasionally also referred to as categorical structure and functional structure (f-structure)" (Asudeh and Toivonen in Heine and Narrog, 2009, p. iii). C-structures are represented as phrase structure trees and model precedence (word order), dominance, constituency and syntactic categories. F-structures are represented as feature structures, which are also known as attributing value matrices.

The f-structure of a sentence contains the grammatical functions that the head verb subcategorizes for (subject, object, etc.) and also represents a range of morphosyntactic information, such as case, agreement features, tense and aspect. According to Asudeh and Toivonen, "F-structure is the level at which abstract syntactic relations are captured, such as agreement, control and raising, binding, and unbounded dependencies. LFG distinguishes sharply between formal structures, such as cstructures and f-structures, and structural descriptions that well-formed structures must satisfy." (in Heine and Narrog, 2009, p. iii).

Recent research about negation in Indonesian conducted by Paul Kroeger (2012) is entitled "External vs. Internal Negation in Indonesian Verbal Clauses". In this study Kroeger differentiate the negation bukan dan tidak. He argues that tidak is a marker of predicate negation, while bukan (in verbal clauses) is a marker for sentential negation. He also mentions that tidak is the default negator in verbal clauses. On the other hand, bukan is obligatory in nominal clauses, but is allowed in verbal clauses only under contrastive, metalinguistic, or narrow focus interpretation. The research inspires the current researcher to analyze other form of negation, specifically the negation jangan.

Some studies have been conducted to explore negation in the framework of LFG. One of them is conducted by Ahmad Alsharif and Louisa Sadler (2009) who study negation in Modern Standard Arabic (MSA). The study shows that there exists the invariant particle maa, the particle laa and its tensed counterparts lam, lan, and laysa which is marked only for subject agreement. Ahmad Alsharif and Loisa 
Sadler (2009) propose an approach to four of these particles. The negation laa, lam, lan show distinctions of tense, occur only with imperfective forms of the verb (excluding the perfective) and must immediately precede the verb itself. They are limited to occurrence in verbal sentences. The researchers propose that the adjacency requirement follows from the fact that these negative particles are non-projecting words adjoined to the (imperfective) V. On the other hand, laysa is a fully verbal element, and is thus a negative verb, occurring only with present tense interpretation. Negations have different and unique properties among languages and also within a language. This paper is aiming at analyzing the structural patterns for the negation jangan.

To achieve the goal of this mini research, first, the paper will argue for the grammatical class and the construction of the negative constituent jangan from the data. Some tests will be applied to describe this word. From the data, it is possible for us to describe the grammatical pattern of the word jangan. It is then followed by the explication of the c-structure and f-structure of sentences containing the negation jangan.

\section{DATA ANALYSIS}

\section{Characteristics of the word jangan}

The data shows that the word jangan can be followed by verbs, adjectives, adverbs, and nouns. The examples below

6) Jangan membaca buku Neg read book 'Don't read that book.'

7) Jangan khawatir. Neg worry

'Don't worry.'

8) Jangan cepat-cepat saat mengendarai mobil. Neg fastly conj drive car 'Don't drive the car fastly.'

9) Jangan kertas yang dipakai untuk hiasan. Neg paper conj use for decoration

'Don't use paper for decoration'

$\begin{array}{clc}\text { 10) Jangan } & \text { dia, karena dia sibuk. } \\ \text { Neg } & \text { PERS.3sg conj PERS.3sg busy }\end{array}$

'Not him, because he is busy.'

11) A: Bu, saya beli tiga kilo gula ya?
B: Jangan tiga, karena kebanyakan. Neg num.three conj many
Satu saja.
'Don't buy three, because it's too much. One is enough.'

show that the word jangan is negating the verb (6), adjective (7), adverb (8), and noun: noun (9), pronoun (10), and numerals (11). itu. that

The word jangan, as seen above, shows that it can be the attribute of certain word class. Subject argument in the sentence can only be filled with pronoun because an imperative is presupposed to be directed to second person. It is often understood and can be omitted in everyday spoken language. The subject in this position cannot be a specific subject. The negation jangan cannot be followed by first person singular pronoun or first person plural pronoun, as seen in the example below: 
12) Saya jangan makan sebelum mandi.*

I neg eat before bath

'I don't eat before taking a bath.'*(not acceptable as imperative)

13) Kamu jangan membuang sampah sembarangan.

PERS.2SG.you neg throw gabage carelessly

"(you) don't throw garbage carelessly.

14) Jangan membuang sampah sembarang.

Neg thow gabage carelessly

Don't throw garbage carelessly.

It is worth to notice the patterns of the word jangan in a passive voice. The subject position can be filled with any noun

when it is in the passive voice. The subject is placed before the word jangan, as shown in the example below:

15) Sampah jangan dibuang sembarangan.

Garbage neg PASS.throw carelessly

Don't throw the garbage carelessly

16) Jangan dibuang sembarangan.

Neg throw carelessly

Don't throw it carelessly.

The negation jangan can be attached to the particle -lah, when it negates predicate whether in active or passive voice.

Besides attached to verb, the negation jangan can also be attached to

17) Kamu khawatir.

You worry

You are worry.

18) Kamu jangan khawatir!

You neg worry

Don't you worry.

19) Kamu senang.

You happy

You are happy.

20) Kamu jangan senang!

You neg happy

Don't be happy.

From these examples, we can see that the word jangan can modify the whole imperative sentence. It functions as a modifier of the whole clause. Interestingly, it doesn't only modify affirmative clauses.

21) Kamu jangan tidak datang ke pesta $=\mathrm{ku}$.

You neg neg come to party=my

You must come to my party. other word classes including adjectives. Indonesian has a unique pattern, in which IP is consisted of NP AP. In this case we can insert the word jangan to this pattern.
The data show that jangan can negate negative predicate, turning the sentence into a strong positive imperative clause, as shown in the example below: 
Not only modify verbs and adjectives that function as predicate in the clause, the word jangan also modifies other word classes,

22) Jangan dia karena dia

Neg pron:3sg conj pron:3sg adj:busy

'Not him, because he is busy.'

23) A: Bu, saya beli tiga kilo gula ya?

$\mathrm{B}$ :

Jangan tiga, karena kebanyakan. Satu saja.

Neg num:three conj many one only

'Don't buy three, because it's too much. One is enough.'

24) Jangan kertas yang dipakai untuk dekorasi

Neg n: paper conj v:use for n:decoration

'Don't use paper for decoration'

From the data, it can be proposed that the word jangan functions as an adverb that modifies verb, adjectives and nouns. An adverb is a word class that can modify verbs, adjectives, nouns, predicates, or clauses (Tampubolon, 2007:54). In addition, according to Kridalaksana (1986) adverbs in Indonesian are used to explain modality, quantity and quality. The negation jangan is considered as an adverb because it has adverb-like behavior. Like other adverbs, the word jangan modifies the constituent that follows it as shown in the examples above.

The structures of the negation jangan

After looking at the behavior of the negation jangan, below is the explication of the c-

C-structure

1. Kamu jangan membaca buku itu. You:2.Sg Neg read book that Don't you read that book. structure and f-structure of sentences containing the negation jangan.

\section{Modifying verb}

The negation jangan is followed by verbs that function as a predicate in the imperative sentences. The negation jangan in imperative clause presupposes a subject (which can be omitted because it is usually understood that the imperative is given to second person). In this paper, we will not discuss ellipsis because we will only see the patterns of sentences with the word jangan. The object of the clause is determined by the predicate the word jangan modifies. The diagrams below show how the word jangan modifies a verb. 


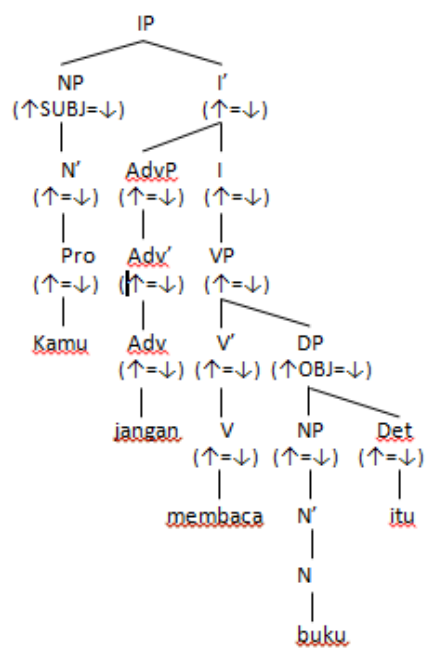

An adverb can take a modifier and form a structural unit with it (Arka, 2003). The negation jangan is an adjunct that which is adjoined Adv to Adv' within AdvP.

The adverb jangan modifies the verb 'membaca' which in this example is a transitive verb which allows a constituent functioning as an object. In the spoken form, the subject 'kamu' can be deleted as it is

Buku itu jangan dibaca

Book that neg PASS.read

Don't read the book.

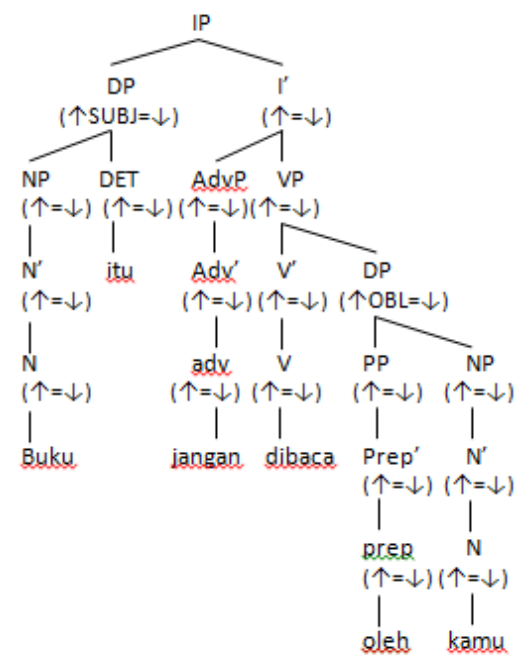

When doing this, the focus is given to the subject of passive voice. However, in a context if the subject is understood, it can

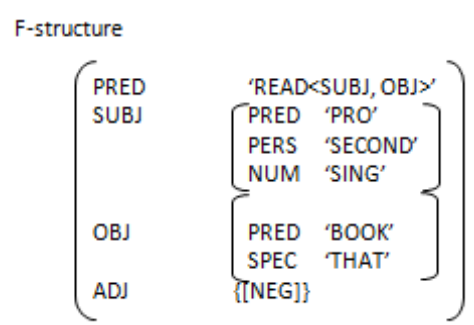

understandable that the clause is intended to be imperative statement. It is not possible to passify imperative in English.

2. Don't read the book.

3. The book don't be read.*

However, it is possible for Indonesian speakers to emphasize the object by stating the passive voice of the statement.

kamu)

you

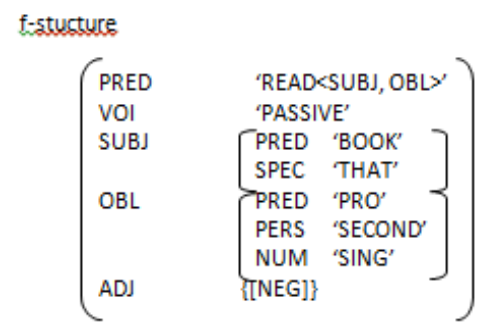

be deleted. The adverb jangan modifies the intransitive verb 'menangis' as seen below. 
5. Kamu jangan menangis

You neg cry

Don't cry.

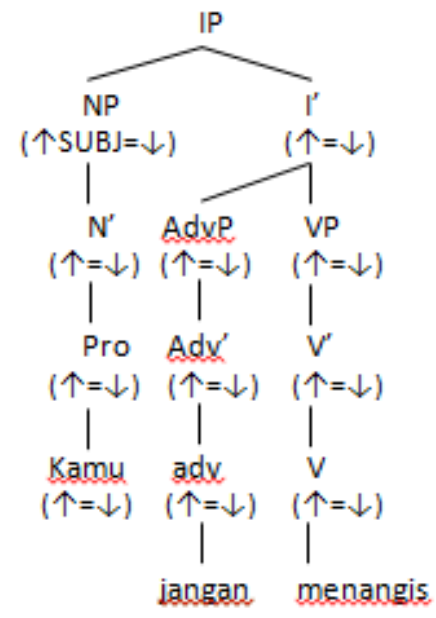

The analysis shows that the negation jangan can be the modifier that negates the verb functioning as predicate in the sentence. It can follow both transitive and intransitive verbs. The constituent that fills the position in the subject is defined by the voice of the imperative. If it is in the active voice, usually the subject is second person

6. Kamu jangan khawatir

You Neg worry

'Don't worry'

As mentioned in the introduction, the negative adverb jangan can negate negative

7. Kamu jangan tidak makan.

You Neg Neg eat

'Don't not eat'

8. Kamu jangan tidak senang dengan makanan itu.

You Neg Neg happy prep:with food that

'Don't dislike that food'

Those are examples of double negatives. The grammatical construction of double

9. Kamu jangan tidak makan

You neg neg eat

You must eat.
F-Structure

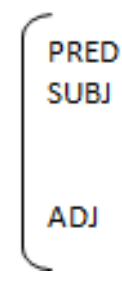

pronoun. On the other hand, if the word jangan negate passive voice, the subject is not restricted.

\section{Modifying Adjectives}

Besides negating verb as a predicate of the sentence, the word 'jangan' can also modify an adjective which functions as a predicate. clause. The example can be seen in the example below: 


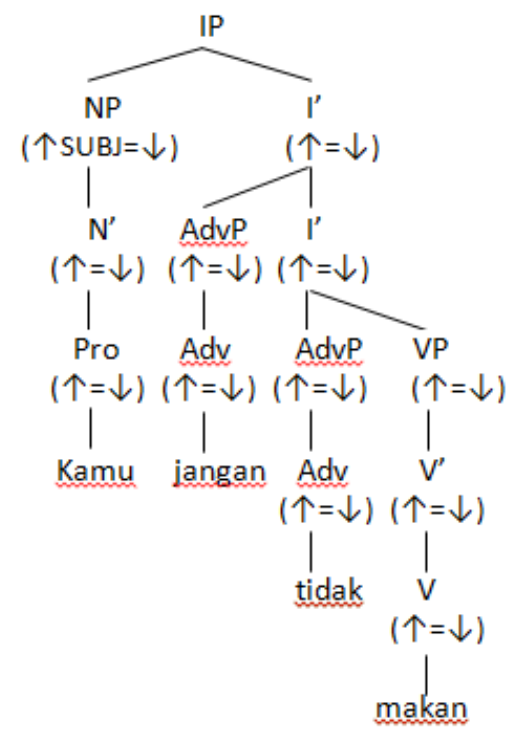

However, it is not possible to negate the word jangan with negative constituent.

Kamu tidak jangan makan.*

Kamu tidak jangan senang dengan makanan itu.*

Kamu jangan jangan makan.*

It is mentioned before that the subject in this grammatical construction cannot be a

10. Mereka jangan sampai pulang.

They neg until go home.

Don't let them go home.

11. Mereka jangan sampai berbicara sembarangan.

They neg until talk carelessly

Don't let them talk carelessly.

In those two sentences above the subject is the agent of the sentence. The preposition "sampai" enables the speaker to express future expectation that negates the

12. Buku itu jangan sampai dibaca.

Book that neg until read

'Don't let that book be read'

As seen above, it is also possible to have the combination of "jangan sampai" in a passive voice. The construction of "jangan sampai" has a tense marker to show imperfective of the action.

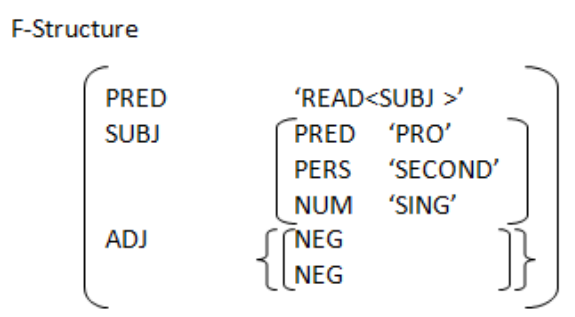

specific subject. The negation jangan cannot be followed by first person singular pronoun or first person plural pronoun. However different construction is applied when using the negation "jangan" with the combination of preposition "sampai" as seen in the data below: proposition. In this case, the subject in the active voice can be in the form of the first person and the third person.

\section{Modifying Adverb}

The adverb jangan does not only function as a negation marker, but it is also functioning as an imperative marker. The data shows that this adverb can be joined to noun phrases and adverb phrases to make it an imperative sentence. 
13. Jangan cepat-cepat. Ada banyak mobil

Don't in a hurry. There lot car

Don't be in a hurry. There are a lot of cars.

The above example is a negative form of imperative sentence. However, it is not possible to have positive imperative construction consisting of adverbs only. Usually to understand the construction of NEG + ADV clause, we need certain pragmatic context.

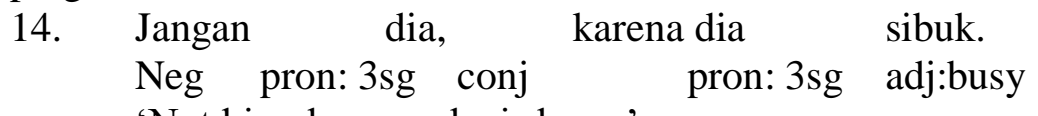

'Not him, because he is busy.'

The above example is a negative form of imperative sentence. However, it is not possible to have positive imperative construction consisting of nouns only. Similar to the previous construction, usually to understand the construction of $\mathrm{ADV}+\mathrm{NP}$, we need certain pragmatic context. From the given data, it can be formulated that the 15. Jangan kamu mencuri.

Neg you steal

'don't you steal'

16. Jangan kamu membunuh.

Neg you kill

'don't you kill'

17. Jangan kamu memakai baju berwarna hijau itu.

Neg you wear dress color green that

Don't wear that green color dress.

This construction is used when we want to topicalize the word jangan or emphasize the prohibition.

\section{Conclusion}

After analyzing the grammatical patterns of the negation jangan from Lexical Functional Grammar perspective, there are several points to be highlighted. From the data it can be proposed that the word jangan functions as an adverb that modifies verb, adjectives and noun. The analysis shows that the negation jangan can negate verbs

\section{Modifying Noun}

We can also have noun after the word jangan. In the example below we have the pronoun 'dia' which is negated by the word jangan.

structure of prohibition is IP = Adv (jangan) X where X: VP, AdjP, NP or AdvP.

\section{Modifying Clause}

The negative constituent jangan can also modify a whole clause. In this case, the word jangan is found in front of a sentence and given emphasis. functioning as predicate in a sentence. It can follow both transitive and intransitive verbs. The constituent that fills the position in the subject is defined by the voice of the imperative. If it is in the active voice, usually the subject is second person pronoun. On the other hand, if the word jangan negates the passive voice, the subject is not restricted. It is possible in Indonesian sentence to have double negations because the negative adverb jangan can negate a negation tidak. It also follows adjectives, 
adverbs, nouns and clauses. The negation jangan also has a different grammatical construction when it follows the preposition sampai. The subject following jangan sampai is not restricted as the subject following jangan is in active voice. The word jangan can be fronted and modify the whole clause. The approach outlined here is preliminary in many ways, and there are a number of open questions which should be explored in future work.

\section{Bibliography}

Alsharif, A and Loisa S. (2009). Negation in modern standard Arabic. LFG Proceeding. Alwi, H. (1992). Modalitas dalam bahasa Indonesia. Yogyakarta: Penerbit Kanisius.

Arka, I W. (2003). Balinese Morphosyntax: A lexical-functional approach. Canberra: Pacific Linguistics.

Bernd H and Heiko N, eds. (2009). The Oxford handbook of linguistic analysis. Oxford: Oxford University Press.

Dalrymple, M. (2001). Lexical Functional Grammar. Volume 3 of Syntax and Semantics. New York: Academic Press.

Kridalaksana, H. (1986). Kelas kata dalam bahasa indonesia. Jakarta: Gramedia.

Lehmann, W. P. (1972). Converging Theories in Linguistics. Language 48 (3): 266 - 275

Sudaryono. (1992). Negasi dalam bahasa Indonesia: Suatu tinjauan sintaktik dan semantik. Jakarta: Departemen Pendidikan dan Kebudayaan.

Talmy, G. (2001). Syntax: An introduction. Amsterdam: John Benjamin Publishing 